\title{
Peer Group Support Dengan Pendekatan Model Keperawatan Health Promotion Model Berpengaruh Terhadap Manajemen Life Style Santri
}

\author{
Khamida \\ Universitas Nahdlatul Ulama Surabaya, khamida@unusa.ac.id \\ Siti Nurjanah. \\ Universitas Nahdlatul Ulama Surabaya, nungj@unusa.ac.id \\ Nur Ainiyah \\ Universitas Nahdlatul Ulama Surabaya, ainiyahannuri@unusa.ac.id
}

\begin{abstract}
Abstrak
Pendahuluan: Pesantren selain sebagai tempat pembelajaran juga dapat menjadi ancaman penularan penyakit jika tidak dikelola dengan baik karena transmisi yang mudah ini disebabkan karena tingkat kepadatan sehingga manajemen life style merupakan kebutuhan yang harus dilakukan karena penghuni pesantren adalah kelompok beresiko terkena penyakit. Tujuan penelitian ini adalah mengetahui pengaruh Peer Group Support terhadap manajemen Life style Santri berdasarkan motivasi dan Perceived benefit of Action santri dengan pendekatan model keperawatan Health Promotion Model. Metode: Desain penelitian quasy ekperimental. Sampel adalah santri mukim di pesantren X dan Y sebesar 100 santri dengan menggunakan simple random sampling. Kelompok perlakuan diberikan penyuluhan dan Peer Group Support sedangkan pada kelompok kontrol hanya diberikan penyuluhan melalui modul. Variabel independen adalah Peer Group Support dan variabel dependennya motivasi santri dan Perceived benefit of Action. Instrumen menggunakan kuesioner. Dianalisis menggunakan uji Wilcoxon Signed Ranks Test, Mann Whitney, Paired $t$ Test, dan Independent t test. Hasil penelitian didapatkan kelompok perlakuan mengalami peningkatan motivasi rerata 5,18, dan perceived benefits of action rerata 4.68. Sedangkan kelompok kontrol peningkatan motivasi rerata sebesar 2,04 dan perceived benefits of action rerata 7,28. Hasil uji Mann Whitney didapatkan $\mathrm{p}=0.00$ dan hasil uji Independent $t$ test didapatkan $\mathrm{p}=0.04$ dimana $\mathrm{p}<0,05$, artinya ada pengaruh Peer Group Support terhadap motivasi perceived benefits of action. Diskusi: Peningkatan motivasi santri dalam menerapkan manajemen life style santri dan perceived benefits of action santri dalam mempersepsikan manfaat manajemen life style diperoleh dari peningkatan pengetahuan melalui penyuluhan dan dukungan yang berasal dari anggota peer group.
\end{abstract}

Kata Kunci: Peer Group Support, Motivasi, Perceived Benefits of Action, Health Promotion Model.

\begin{abstract}
Introduction: The Islamic boarding school apart from being a place of learning, can also be a threat of disease transmission if not managed properly, because easy transmission due density in pesantren, so that do life style management is a necessity because the occupants are risk of disease. The purpose of this reseacrh was to determine of effect Peer Group Support to santri life style management based on motivation and santri Perceived benefit of Action with the Health Promotion Model nursing model approach. Method: The design research use Quasy experimental, sample was 100 santri's at Islamic bording school X and Y use simple random sampling method. The treatment group was given counseling and Peer Group Support while
\end{abstract}


the control group was only given counseling trough modules. The independent variable is Peer Group Support and the dependent variable is santri motivation and Perceived benefit of Action. The instrument use a questionnaire and Analyzed by Wilcoxon Signed Ranks Test, Mann Whitney, Paired t Test, and Independent $t$ test. Result: The results showed the treatment group experienced an increase in mean motivation of 5.18, and the average perceived benefit of action was 4.68. While the control group increased mean motivation by 2.04 and the average perceived benefit of action was 7.28. The Mann Whitney test results obtained $p=0.00$ and the results of the Independent test $t$ test obtained $p=0.04$ where $p<0.05$, meaning that there is the influence of Peer Group Support on the motivation of the perceived benefits of action. Discuss: Increased motivation of santri's in implementing santri's life style management and perceived benefits of action of muslim students in perceiving the benefits of life style management were obtained from increased knowledge through counseling and support from peer group members.

Keyworld: Peer Group Support, Perceived Benefits of Action Motivation, Health Promotion Model

\section{PENDAHULUAN.}

Pondok pesantren di Indonesia memiliki beberapa permasalahan. Permasalahan tersebut meliputi penyimpangan perilaku dan masalah kesehatan (penyakit). Penyakit scabies dan pedikulosis merupakan penyakit yang menjadi masalah klasik di semua pesantren dan saat ini permasalahan tersebut masih belum tertangani dengan baik

Menurut laporan Departemen Agama RI tahun 2011 Jumlah pondok pesantren di Indonesia mencapai 28.691 pesantren total santri 4.028.660 terdiri dari 2.060.029 santri laki-laki 1.968.631 santri perempuan. Di Jawa Timur, terdapat 6017 pondok jumlah santri putra 511.149 dan santri putri 455.807 Orang (Kementrian Agama, 2012). Hasil penelitian (Fatma-wati, T and Saputra, N ( 2016) menunjukkan bahwa di dua pondok pesantren masih didapatkan perilaku hidup bersih sehat kurang baik di Pondok Pesantren A sebanyak 48,1\% dan di Pondok Pesantren B 32,3\%

Manajemen life style santri merupakan perilaku santri dalam mengatur, melaksanakan pola hidup bersih dan sehat. Manajemen life style ini dilakukan melalui upaya promotif, preventif, kuratif serta rehabilitatif, sehingga dapat meningkatkan derajat kesehatan santri. Manajemen life style perlu diterapkan oleh santri dalam menjalankan kehidupannya di pondok pesantren agar, meningkatkan produktifitasnya, meminimalkan resiko terkena penyakit. Pesantren adalah tempat para santri murid menuntut ilmu agama dan ilmu lainnya (Effendy, 2009). Fungsi pesantren selain sebagai tempat pem-belajaran, ternyata pesantren menjadi tempat penularan 
penyakit jika tidak dikelola dengan baik. Hal ini dikarenakan transmisi penyakit yang terjadi tingkat kepadatan di pesantren sangat tinggi, oleh karena itu penting untuk dilakukan sehingga manajemen life style yang tepat. Mana-jemen life style merupakan kebutuhan yang harus dilakukan karena penghuni pesantren adalah kelompok beresiko terkena penyakit.

Model promosi kesehatan telah banyak dikembangkan oleh para ahli salah satunya model promosi kesehatan yang dikembangkan oleh Nolla Pender. Model ini menggabungkan 2 teori yaitu teori nilai harapan (Expectancy Value) dan teori kognitif sosial (Social Cognitive Theory) yang konsisten dengan semua teori yang memandang pentingnya promosi kesehatan dan pencegahan penyakit adalah suatu yang hal logis dan ekonomis.

Promosi kesehatan yang digunakan dalam kelompok kecil lebih efektif dibandingkan dengan metode ceramah. Setiap orang yang terlibat dalam diskusi kelompok bisa saling berdiskusi, sharing pengalaman tentang kondisi tubuh atau psikologisnya. Cara ini tidak mengeluarkan biaya yang banyak bila dibandingkan dengan upaya kuratif. Dalam diskusi kelompok bisa dilakukan melalui Support education, peer group, sharing konseling, dan Self Help Groups

Edukasi peer group akan membuat individu berusaha untuk memenuhi kebutuhan psikologis, seperti kebutuhan untuk menyesuaikan diri dengan temanteman sebaya dan diterima oleh mereka, kebutuhan untuk bertukar pikiran dan berbagi perasaan, pendapat dan pengalaman yang nantinya akan bermanfaat bagi mereka sendiri dalam mengembangkan dan meningkatkan konsep dirinya. Melalui metode ini juga santri dapat menemukan nilai-nilai kehidupan sebagai pegangan hidup, dan kebutuhan untuk menjadi lebih mandiri terlebih pada pemahaman konsep sehat dan sakit. Suasana edukasi peer group, para santri akan merasa lebih mudah membicarakan topik/ persoalan-persoalan kesehatan yang mereka hadapi bersama di pesantren, di mana mereka akan dapat leluasa dalam bergaul dan saling terbuka dalam membahas persoalan kesehatan melalui bentuk diskusi yang hangat dan akrab, sehingga mereka akan dapat saling memberikan dukungan, motivasi.

Health Promotion Model revisi menjelaskan tentang variabel-variabel yang berdampak pada perilaku kesehatan seseorang, yaitu: Karakteristik dan pengalaman individu, aspek kognisi dan afeksi 
dari perilaku khusus dan perilaku yang diharapkan. Karakteristik dan pengalaman individu terdiri dari perilaku sebelumnya yang terkait dan faktor personal,yang meliputi faktor biologis, psikologis (motivasi) dan sosial budaya. Aspek kognisi dan afeksi dari perilaku khusus terdiri dari: Perceived benefit of Action (manfaat tindakan yang dirasakan), perceived barriers to action (hambatan tindakan yang dirasakan), Perceived self efficacy (kemajuan diri yang dirasakan), activity-related affect (sikap yang berhubungan dengan aktivitas), pengaruh interpersonal dan pengaruh situasional. Perilaku yang diharapkan terdiri dari komitmen terhadap rencana dan kebutuhan pilihan yang mendesak (Alligood, 2017).

Tujuan penelitian ini adalah mengetahui pengaruh Peer Group Support terhadap manajemen Life style Santri berdasarkan motivasi dan Perceived benefit of Action santri dengan pendekatan model keperawatan health promotion model.

\section{METODE}

Desain penelitian menggunakan quasy ekperimental (pre-post test control group design). Sampel adalah santri mukim di pondok pesantren X dan Y sebesar 100 santri dengan menggunakan simple random sampling. Pada kelompok perlakuan dilakukan suatu perlakuan penyuluhan dan Peer Group Support sedangkan pada kelompok kontrol hanya diberikan penyuluhan. Pertemuan dalam peer group dilakukan sebanyak 8 kali pertemuan dengan durasi 60 menit setiap sesi. Variabel independen adalah Peer Group Support dan variabel dependennya adalah motivasi santri dan Perceived benefit of Action. Instrumen menggunakan kuesioner. Dilakukan uji normalitas Kolmogorov-Smirnov, apabila data berdistribusi normal, maka data dianalisis menggunakan Uji paired $t$ test (menganalisis perbedaan sebelum dan sesudah diberikan perlakuan baik kelompok perlakuan maupun kelompok kontrol, dan Uji independen $t$ test (menganalisis perbedaan kedua kelompok (kelompok perlakuan dan kelompok kontrol). Jika hasil uji Kolmogorov-Smirnov data tidak berdistribusi normal, maka ketentuan uji paired $t$ test diganti dengan uji Wilcoxon Signed Ranks Test, dan uji independent t test diganti dengan menggunakan uji Mann-Whitney.

\section{HASIL PENELITIAN}

Hasil penelitian aplikasi Peer Group Support terhadap Manajemen Life Style Berdasarkan Motivasi Dan Perceived Benefit Of Action Santri Dengan Pendekatan Model 
Keperawatan Health Promotion Model

adalah sebagai berikut:

Tabel 1: Distribusi Motivasi Santri Sebe-lum dan Sesudah diberikan Peer Group Support

\begin{tabular}{lccccc}
\hline Motivasi & $\mathrm{n}$ & Mean & Min-Mak & SD & $\mathrm{P}$ \\
\hline \multicolumn{4}{l}{ Kelompok Perlakuan } \\
Pre Test & 50 & 19,04 & $14-22$ & 1,484 & Wilcoxon \\
Post Test & 50 & 23,30 & $19-24$ & 1,266 & $\mathrm{P}=0,000$ \\
\hline \multicolumn{6}{l}{ Kelompok Kontrol } \\
Pre Test & 50 & 19,06 & $14-22$ & 1,434 & Wilcoxon \\
Post Tes & 50 & 21,10 & $18-23$ & 1,313 & $\mathrm{P}=0,000$ \\
\hline
\end{tabular}

Tabel 2: Distribusi Motivasi Santri Sebelum dan Sesudah diberikan Peer Group Support

\begin{tabular}{lcccccccc}
\hline \multirow{2}{*}{\begin{tabular}{c} 
Motiva \\
\multicolumn{1}{c}{ si }
\end{tabular}} & \multicolumn{4}{c}{ Perlakuan } & \multicolumn{4}{c}{ Kontrol } \\
\cline { 2 - 9 } & \multicolumn{2}{c}{ Pre } & $\%$ & Post & \multicolumn{3}{c}{ Pre } & \multicolumn{3}{c}{ Post } \\
\hline Rendah & 1 & 2 & 0 & 0 & 1 & 2 & 0 & 0 \\
Cukup & 27 & 54 & 1 & 2 & 27 & 54 & 7 & 14 \\
Tinggi & 22 & 44 & 49 & 98 & 22 & 44 & 43 & 86 \\
\hline Total & 50 & 100 & 50 & 100 & 50 & 100 & 50 & 100 \\
\hline
\end{tabular}

Tabel 3: Distribusi Perceived Benefit of Action Santri Sebelum dan Sesudah diberikan Peer Group Support

\begin{tabular}{|c|c|c|c|c|c|}
\hline $\begin{array}{l}\text { Perceived } \\
\text { Benefit of } \\
\text { Action }\end{array}$ & $\mathrm{n}$ & Mean & $\begin{array}{l}\text { Min- } \\
\text { Mak }\end{array}$ & SD & $\mathrm{P}$ \\
\hline \multicolumn{6}{|c|}{ Kelompok Perlakuan } \\
\hline Pre Test & 50 & 44,08 & $33-55$ & 4,120 & \multirow{2}{*}{$\begin{array}{c}\text { Paired } t \\
\text { test } \\
\mathrm{P}=0,000\end{array}$} \\
\hline Post Test & 50 & 48,76 & $34-58$ & 4,779 & \\
\hline \multicolumn{6}{|c|}{ Kelompok Kontrol } \\
\hline Pre Test & 50 & 41,12 & $29-49$ & 3,674 & \multirow{2}{*}{$\begin{array}{c}\text { Paired } t \\
\text { test } \\
\mathrm{P}=0,000\end{array}$} \\
\hline Post Tes & 50 & 48,4 & $40-60$ & 4,360 & \\
\hline
\end{tabular}

Tabel 4: Distribusi Peningkatan (Selisih Pre dan Post) Motivasi dan Perceived Benefit of Action Santri Sebelum dan Sesudah diberikan Peer Group Support

\begin{tabular}{lcccc}
\hline Komponen & Mean & $\begin{array}{c}\text { Min- } \\
\text { Mak }\end{array}$ & SD & $\mathrm{P}$ \\
\hline $\begin{array}{l}\text { Motivasi } \\
\text { Perlakuan }\end{array}$ & 5,18 & $0-12$ & 4,120 & $\begin{array}{c}\text { Mann } \\
\text { Kontrol }\end{array}$ \\
2,04 & $0-8$ & 4,779 & $\begin{array}{c}\text { Whitney } \\
\mathrm{P}=0,000\end{array}$ \\
\hline $\begin{array}{l}\text { Perceived Benefit of Action } \\
\text { Perlakuan }\end{array}$ & 4,68 & $0-$ & 3,674 & $\begin{array}{c}\text { Independ } \\
\text { ent t test }\end{array}$ \\
Kontrol & 7,28 & $\begin{array}{c}14 \\
-4\end{array}$ & 4,360 & $\mathrm{P}=0,004$ \\
& & 15 & & \\
\hline
\end{tabular}

\section{PEMBAHASAN}

Manajemen life style santri merupakan perilaku santri dalam mengatur dan melaksanakan pola hidup bersih dan sehat yang meliputi upaya promotif, preventif, kuratif dan rehabilitatif, dengan tujuan untuk meningkatkan derajat kesehatan santri. Hasil penelitian pada tabel 2 menunjukkan bahwa motivasi santri untuk menjalankan manajemen life style santri sebelum diberikan Peer Group Support pada kelompok perlakuan dan kelompok kontrol keduanya sebagaian besar (27\%) mempunyai motivasi cukup dalam menjalankan manajemen life style santri. Sedangkan untuk motivasi santri sesudah diberikan Peer Group Support pada kelompok perlakuan didapatkan hampir seluruhnya $(98 \%)$ mempunyai motivasi tinggi dalam menjalankan manajemen life style santri, dan pada kelompok kontrol didapatkan sebagian besar (86\%) juga 
mempunyai motivasi tinggi dalam menjalankan manajemen life style santri.

Motivasi merupakan salah satu faktor personal yang mempengaruhi perilaku kesehatan seseorang. Motivasi santri untuk menerapkan manajemen life style di kehidupan pondok pesantren sangat penting. Karena jika seseorang santri sudah mempunyai dorongan yang kuat dari dalam dirinya maka praktik menjalankan manajemen life style dengan berperilaku hidup bersih dan sehat akan terwujud. Karena dorongan dalam diri individu dapat mewujudkan motivasi untuk melakukan suatu aktivitas. Atas dasar motivasi inilah manajemen life style dapat terlaksana dengan baik. Terdapat korelasi positif antara motivasi hidup sehat dengan perilaku hidup sehat. Kekuatan korelasi tersebut sebesar ry2=0,61 (Wihardjo1 and Nurani, 2017).

Berdasarkan hasil penelitian baik kelompok perlakuan maupun kelompok kontrol sama-sama mengalami peningkatan motivasi dalam menjalankan manajemen life style, namun pada kelompok perlakuan mengalami peningkatan lebih besar, hal ini dapat dilihat pada tabel 4 yaitu kelompok perlakuan mengalami peningkatan dengan mean (rerata) 5,18, sedangkan pada kelompok kontrol mean (rerata) peningkatannya sebesar 2,04. Berdasarkan hasil uji
Mann Whitney didapatkan $\mathrm{p}=0.00$ dimana $\mathrm{p}$ $<0,05$, artinya ada pengaruh Peer Group Support terhadap motivasi santri dalam mene-rapkan manajemen life style. Pada kelompok perlakuan selain diberikan penyuluhan manajemen life style juga diberikan peer group support yaitu pertemuan peer group dilakukan sebanyak 8 kali pertemuan dengan durasi 60 menit setiap sesi. Peer group support adalah dukungan yang diberikan oleh seseorang yang telah mengalami kesulitan emosional kepada seseorang yang mengalami kesulitan yang sama dengan mendengarkan keluhan dan berbagi pengalaman yang telah mereka alami (Hannu L.T.Keikkinen, 2012).

Edukasi peer group akan membuat individu berusaha untuk memenuhi kebutuhan psikologis, seperti kebutuhan untuk menyesuaikan diri dengan temanteman sebaya dan diterima oleh mereka, kebutuhan untuk bertukar pikiran dan berbagi perasaan, pendapat dan pengalaman yang nantinya akan bermanfaat bagi mereka sendiri dalam mengembangkan dan meningkatkan konsep dirinya. Melalui metode ini juga anggota kelompok dapat menemukan nilai-nilai kehidupan sebagai pegangan hidup, dan kebutuhan untuk menjadi lebih mandiri terlebih pada pemahaman konsep sehat dan sakit. Suasana 
edukasi peer group, para santri akan merasa lebih mudah membicarakan topik/ persoalan-persoalan kesehatan yang mereka hadapi bersama di pesantren, di mana mereka akan dapat leluasa dalam bergaul dan saling terbuka dalam membahas persoalan kesehatan melalui bentuk diskusi yang hangat dan akrab, sehingga mereka akan dapat saling memberikan dukungan atau motivasi antar sesama santri. Untuk meningkatkan motivasi berperilaku hidup sehat, perlu dilakukan pengakuan atau memperhatikan kebutuhan sosial mereka, meyakinkan kepada mereka bahwa setiap orang adalah penting dan berguna bagi masyarakat (Notoadmojo, 2010). Terjadinya pening-katan motivasi mene-rapkan manajemen life style santri diperoleh dengan dukungan yang berasal dari anggota peer group.

Perceived Benefit of Action merupakan manfaat tindakan yang dirasakan oleh santri dalam menerapkan manajemen life style. Berdasarkan hasil penelitian pada tabel 3 didapatkan Pada kelompok kontrol Perceived Benefit of Action sebelum diberikan peer group support dengan skor mean (rerata) 44,08, nilai minimal 33, nilai maksimal 55 dan standar deviasi 4,120. Dan sesudah diberikan peer group support didapatkan skor mean (rerata) 48,76, nilai minimal 34, nilai maksimal 58 dan standar deviasi 4,779.

Health Promotion Model Pender menjelaskan bahwa behaviour specific cognition and affect yang meliputi perceived benefits of action, perceived barriers to action, perceived self-efficacy, activity related affect dapat mempengaruhi perilaku individu dalam melakukan perilaku kesehatan (Tomey, 2006). Perceived benefits of action merupakan manfaat tindakan yang secara langsung memotivasi perilaku dan tidak langsung mendetermin rencana kegiatan untuk mencapai manfaat sebagai hasil. Pada penelitian ini perceived benefits of action merupakan persepsi santri dari kemanfaatan menerapkan manajemen life style. Sebelum diberikan diberikan peer group support hampir setengah santri mempunyai persepsi negatif terhadap manajemen life style, hasil diskusi saat pelaksanaan peer group support sebagian santri menyatakan bahwa selama ini sudah terbiasa dan diperbolehkan pinjam meminjam sisir, handuk, pakaian, bantal, sabun antar sesama santri yang sekamar. Hal ini yang menyebabkan sangat berisiko terjadi penularan penyakit, terutama penyakit kulit. Namun setelah diberikan penyuluhan ataupun peer group support baik kelompok perlakuan maupun kelompok 
kontrol keduanya terjadi perubahan persepsi menjadi positif.

Berdasarkan hasil penelitian baik kelompok perlakuan maupun kelompok kontrol sama-sama mengalami peningkatan skor perceived benefits of action dalam mempersepsikan manajemen life style, namun pada kelompok kontrol mengalami peningkatan lebih besar, hal ini dapat dilihat pada tabel 4 yaitu kelompok perlakuan mengalami peningkatan dengan mean (rerata) 4.68, sedangkan pada kelompok kontrol mean (rerata) peningkatannya sebesar 7.28. Berdasarkan hasil uji Independent $t$ test didapatkan $\mathrm{p}=0.04$ dimana $\mathrm{p}<0,05$, artinya ada pengaruh Peer Group Support terhadap perceived benefits of action dalam mempersepsikan manfaat mana-jemen life style. Pada kelompok kontrol meskipun tidak diberikan peer group support namun tetap diberikan penyuluhan melalui media modul manajemen life style. Dengan adanya penyuluhan ini dapat meningkatkan pengetahuan santri. Pengetahuan santri mempengaruhi perceived benefits of action santri dalam mempersepsikan manfaat manajemen life style santri. Tingkat pengetahuan sesorang akan mempengaruhi persepsinya dan persepsi sesorang akan berpengaruh pada perilaku kesehatan individu tersebut (Ahmad
Kholid, 2014). Pada kelompok perlakuan yang diberikan penyuluhan dan peer group support didapatkan hampir seluruh santri mengalami peningkatan skor, sebagian kecil mempunyai skor yang sama sebelum diberikan perlakuan dan tidak ada satupun santri yang mengalami penurunan skor perceived benefits of action santri dalam mempersepsikan manfaat manajemen life style, artinya semakin positif persepsi santri terhadap manfaat manajemen life style santri setelah diberikan peer Group Support.

\section{SIMPULAN}

Simpulan dalam penelitian ini adalah ada pengaruh Peer Group Support terhadap motivasi dan perceived benefits of action santri dalam menerapkan dan mempersepsikan manfaat manajemen life style santri. Peningkatan motivasi santri dalam menerapkan manajemen life style santri dan perceived benefits of action santri dalam mempersepsikan manfaat manajemen life style diperoleh dari peningkatan pengetahuan melalui penyuluhan dan dukungan yang berasal dari anggota peer group.

\section{REFERENSI.}

$\begin{array}{rlr}\text { Ahmad Kholid } & (2014) & \text { Promosi } \\ \text { Kesehatan,dengan } & \text { Pendekatan } & \text { Teori }\end{array}$


Perilaku, Media dan Aplikasinya. 2nd edn. Jakarta: Rajawali Pers: Rajawali Pres.

Alligood, M. R. (2017) Pakar Teori Keperawatan dan Karya Mereka. Edisi Indo. Edited by A. Y.; S Hamid and I. Kusman. singapore.

Effendy, F. dan M. (2009) Keperawatan Kesehatan Komunitas: Teori dan Praktik. Jakarta: Salemba Madika.

Fatmawati, T, Y. and Saputra, N, E. (2016) 'Perilaku Hidup Bersih dan Sehat Santri Pondok Pesantren As'ad dan Pondok Pesantren Al Hidayah', Jurnal Psikologi jambi, 1(1), pp. 29-35.

Hannu L.T.Keikkinen, H. J. and P. T. (2012) Peer-Group Mentoring for Teacher Development. London and New York; Routledge.
Kementrian Agama (2012) 'Statistik Pendidikan Diniyah dan Pesantren', 446, pp. 29-58.

Notoadmojo, S. (2010) Ilmu Perilaku Kesehatan. Jakarta: Rineka Cipta.

Tomey, M. R. A; A. M. (2006) Nursing Theorists and Their Work, Seventh Ed. Elsevier.

Wihardjo1, R. S. D. and Nurani, dan Y. (2017) 'Studi Korelasi Antara Pengetahuan Lingkungan, Motivasi Hidup Sehat, Dan Kepedulian Lingkungan Terhadap Perilaku Hidup Sehat Mahasiswa Fakultas Ilmu Pendidikan Universitas Negeri Jakarta', 2(2), pp. 230241. 